University of Nebraska - Lincoln

DigitalCommons@University of Nebraska - Lincoln

Publications, Agencies and Staff of the U.S.

Department of Commerce

U.S. Department of Commerce

6-1998

Evolutionarily Significant Units, Distinct Population Segments, and the Endangered Species Act: Reply to Pennock and Dimmick

Robin Waples

NOAA, robin.waples@noaa.gov

Follow this and additional works at: https://digitalcommons.unl.edu/usdeptcommercepub

Waples, Robin, "Evolutionarily Significant Units, Distinct Population Segments, and the Endangered Species Act: Reply to Pennock and Dimmick" (1998). Publications, Agencies and Staff of the U.S. Department of Commerce. 433.

https://digitalcommons.unl.edu/usdeptcommercepub/433

This Article is brought to you for free and open access by the U.S. Department of Commerce at DigitalCommons@University of Nebraska - Lincoln. It has been accepted for inclusion in Publications, Agencies and Staff of the U.S. Department of Commerce by an authorized administrator of DigitalCommons@University of Nebraska - Lincoln. 


\title{
Evolutionarily Significant Units, Distinct Population Segments, and the Endangered Species Act: Reply to Pennock and Dimmick
}

\author{
ROBIN S. WAPLES \\ Conservation Biology Division, National Marine Fisheries Service, Northwest Fisheries Science Center, \\ 2725 Montlake Boulevard East, Seattle, WA 98112, U.S.A., email robin.waples@noaa.gov
}

\section{Introduction}

Taxonomy and systematics have long been characterized by heated debates over methodology and pointed exchanges between "lumpers" and "splitters." Therefore, when I wrote the paper (Waples 1991) outlining the concept of evolutionarily significant units (ESUs) for identifying "distinct population segments" of Pacific salmon (Oncorbynchus spp.) under the U.S. Endangered Species Act (ESA), I realized that any attempt to identify conservation units below the species level would also generate a good deal of scientific discussion. This has proved to be the case (e.g., Dizon et al. 1992; Rojas 1992; Moritz 1994a; Vogler \& DeSalle 1994; Nielsen 1995).

At the same time, a parallel discussion has taken place of which the primary focus is not biological issues but rather the degree to which the ESU concept satisfies the original intent of the U.S. Congress and the ESA itself (for divergent views on this issue see Gleaves et al. 1992; Rohlf 1994). The recent essay in these pages by Pennock and Dimmick (1997) follows in this tradition. Pennock and Dimmick argue that the ESU concept adopted as policy by the National Marine Fisheries Service (NMFS; 1991 Federal Register 56:58612) for identifying distinct population segments of Pacific salmon under the ESA (1) is inconsistent with the original intent of Congress, (2) unduly narrows the scope of populations that can be considered distinct under the ESA, and (3) limits flexibility under the ESA.

The comments below address these criticisms as they apply to the NMFS ESU policy for salmon.

\section{Inconsistency}

An examination of the legislative and legal history of the ESA does not support Pennock and Dimmick's claim

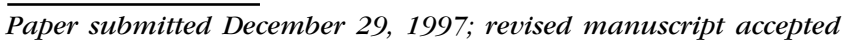
February 18, 1998. that the NMFS ESU policy is inconsistent with the intent of Congress or the Act. Three basic principles guided development of the policy: (1) the clear intent of the framers of the ESA to use it to protect genetic diversity (93rd Congress, 1st Session, 1973, H.R. Report 412); (2) the 1979 directive that the government agencies involved list populations "sparingly and only when the biological evidence indicates that such action is warranted" (96th Congress, 1st Session, 1979, Senate Report 151); and (3) the stipulation in the ESA itself (Sec. 4(b)(1)(A)) that listing decisions be based "solely on the basis of the best scientific and commercial data available." This last point was re-emphasized during the 1982 amendment process, which added the word "solely" to the passage cited above. This addition was "intended to remove from the process of listing and delisting of species any factor not related to the biological status of the species" (97th Congress, 2d Session, 1982, H.R. Report 567, Part 1).

Collectively, these provisions leave no doubt that ESA listing determinations should be based strictly on the biology of the organisms involved. The importance of identifying conservation units that are biologically meaningful is evident when one considers that the fundamental goal of the ESA is to prevent extinctions. Extinction is a biological process that involves the irreversible loss of genetic material. Therefore, units for conservation under the ESA must have an underlying biological basis if the goals of the act are to be accomplished.

In contrast to this direction from Congress and the ESA itself, Pennock \& Dimmick (p. 616) apparently reject all biologically based formulations of conservation units: "All of these proposed definitions for the ESU (referring to papers by Moritz [1994a and $b$ ], Vogler \& Desalle [1994] and Mayden \& Wood [1995], as well as me), however, if used as a definition for distinct population segments, would narrow the original intent behind the phrase to include only populations that are genetically or morphologically distinct." Pennock and Dimmick seem to believe that the goals of the ESA can be accomplished 
through a framework in which the use of biological criteria for defining "species" under the ESA is optional. This view is difficult to reconcile with the clear guidance that ESA species be defined on a biological basis.

\section{Narrowness}

Pennock and Dimmick argue that the ESU policy unduly narrows the scope of populations that can be protected under the ESA because of the requirement that they meet certain criteria to be considered distinct. They show that, historically, populations have been listed under the ESA without evidence of morphological or genetic distinctness, and they argue (p. 616) that "A rigid set of a priori criteria for the identification of distinct population segments cannot anticipate all of the unique and unpredictable problems that diverse taxa each with unique conservation problems may present." On the other hand, they also criticize the ESU concept because it will not always lead to a "clear and consistent" interpretation of the term "distinct population segment" because many of the factors that must be considered in making ESU determinations are open to multiple interpretations within the scientific community. Each of these arguments-that the NMFS ESU concept is too rigid and that it is too ambiguous-has some merit, and each has been made previously by others, although generally not in the same essay.

Given that prior to 1991 there were no official guidelines for interpreting the phrase "distinct population segment" in the ESA, Pennock and Dimmick are correct that the ESU policy (or any other framework that might be developed) narrows the range of populations that might be considered "distinct." That is, after all, the function of a policyto provide focus and guidance. Regarding ambiguity, application of the ESU concept as outlined for Pacific salmon generally will involve some professional judgement, primarily in how to weigh and synthesize diverse types of information (Waples 1991, 1995). It is certainly possible to envision a simpler "objective" process for identifying distinct population segments, but it is not so easy to find a simpler framework that will produce biologically meaningful results across a wide range of applications.

\section{Flexibility}

A major theme of the essay by Pennock and Dimmick (p. $617)$ is that the ESU policy "greatly erodes" the flexibility of government agencies to "confront the wide variety of conservation problems presented by the interactions between humans and other species." They make two main points with respect to flexibility: (1) one principal reason Congress added the distinct population provision to the ESA was to give the government agencies flexibil- ity to list populations of species that are healthy in other parts of their range, and (2) populations can be important for many reasons, and the historical approach can integrate factors not easily accommodated by the ESU concept, such as demographic, behavioral, economic, and cultural justifications for preserving populations.

The first point is accurate, but the relevance to the ESU policy is not clear. Neither the ESU concept nor the NMFS salmon policy in any way restricts the ability of the ESA to provide different levels of protection to units below the species level.

Pennock and Dimmick are also correct in their second point, that the significance of populations can be measured in a variety of ways, and that factors such as economic and cultural value are not considered in the NMFS ESU concept. It is important, however, to make a distinction between the various benefits of biological conservation and the process of identifying conservation units. The ESA (Sec. 2(a)(3)) points out that species are of "esthetic, ecological, educational, historical, recreational, and scientific value to the Nation and its people." These are all good reasons for conserving biological diversity in general, but they do not provide a sound basis for defining conservation units or deciding which ones to protect. If efforts designed to avoid extinctions are to be effective in the long term, they cannot be based on our perceptions of which particular species or populations are of recreational, aesthetic, or economic value because these perceptions are ephemeral on evolutionary time scales - the only time scale for which the concept of extinction is meaningful.

Pennock and Dimmick's criticism that the NMFS ESU policy neglects demographic and behavioral attributes of populations reflects a misunderstanding of the ESU concept and how it has been applied. A fundamental theme of the NMFS ESU policy is use of a holistic approach to identify conservation units. In fact, demographic and behavioral traits (e.g., age structure, fecundity, run and spawn timing, juvenile and ocean migration patterns) receive a great deal of consideration in our ESU determinations. It is not clear why Pennock and Dimmick haven't realized the importance of demographic and behavioral factors in ESU determinations for Pacific salmon, but it may be because salmon biologists generally refer to these as "life-history" traits rather than behavioral or demographic ones.

\section{Alternatives to the ESU}

A major weakness in the essay by Pennock and Dimmick is that, although they are critical of the ESU concept, they do not propose an alternative method for interpreting the phrase "distinct population segment" in the act. The ESA is one of the most powerful pieces of environmental legislation in the world, and its use can mobilize considerable resources toward biological conservation. 
Invoking protective measures under the ESA, however, can also have substantial economic and social consequences. It is essential, therefore, that government agencies use the ESA wisely and be able to articulate a clear rationale for their decisions. This is difficult if they cannot describe a procedure for identifying units that can be considered species under the ESA.

Rather than providing any explicit guidance, Pennock and Dimmick emphasize the great flexibility in listing decisions allowed under the "historic" approach to identifying distinct population segments. As evidence of successes during that historic period, Pennock and Dimmick tabulate a number of distinct population segments that were listed as ESA species in the absence of any policy guidance, and they discuss the wide variety of justifications used to support those listing determinations. This flexibility is a sword that cuts two ways. Missing from their essay is any mention of numerous petitions for ESA listing of populations that were turned down by the U.S. Fish and Wildlife Service because they determined, again using a wide variety of rationales, that the populations were not "distinct."

\section{Applications of the NMFS ESU Concept}

Any framework for defining conservation units can best be evaluated by considering how it has been applied. Since 1991, the NMFS ESU policy has been used to identify at least 50 ESUs from seven species of Pacific salmon and anadromous trout. Several important points can be made from a review of this substantial body of evidence (for discussion and more examples, see Waples 1995).

First, the ESU policy has been widely used to confer different levels of protection on different population groups. The ESUs of chinook (O. tshawytscha), sockeye (O. nerka), and coho salmon (O. kisutch) and of steelhead (O. mykiss) and cutthroat trout $(O$. clarkii) are listed as distinct population segments under the ESA, whereas other ESUs of the same species remain unlisted. In its 1996 listing proposal for steelhead from Washington, Oregon, Idaho, and California (1996 Federal Register 61:41541), the NMFS identified five ESUs as endangered, five as threatened, one as a "candidate species" for possible future listing, and four that were neither threatened nor endangered. The proposal took advantage of the full range of flexibility for listing determinations available under the ESA.

Second, each of the salmon ESUs identified by the NMFS represents one or more geographically coherent populations. The appropriate geographic scale for defining the ESUs was determined on a case-by-case basis using all available biological and environmental information (ecology, life history, genetics, morphology, behavior, habitat characteristics, etc.).

Third, the NMFS has pursued to completion ESU determinations that could easily have ended in regulatory limbo under the historic approach favored by Pennock and Dimmick. For example, in 1993 the NMFS concluded that a petition for listing of winter steelhead trout from the Illinois River in southern Oregon was not warranted because this population did not by itself constitute an ESU. Rohlf (1994) cited this as an example of the failure of the NMFS ESU policy. The NMFS did not stop with this negative finding, however, and in 1993 it initiated a larger status review to identify the ESU that contained the Illinois River population. The result of that broader review was a proposal to list as threatened all steelhead trout populations in the Klamath Mountains region of southern Oregon and northern California, including the Illinois River population (1995 Federal Register 60:14253). Application of the NMFS ESU policy in this case led to a proposal for legal protection for many more local populations than were included in the original petition.

Fourth, in applying the ESU concept to Pacific salmon, the NMFS has not shirked its stewardship responsibility or its mandate under the ESA to protect threatened and endangered species. In spite of pressure from interest groups and the possibility of substantial economic, social, and political effects of ESA actions, the NMFS has listed salmon populations of several species from large geographic areas. Therefore, it is difficult to argue that the ESU policy has reduced the level of protection afforded these valuable resources. Rather, the policy has provided a framework to efficiently identify units for conservation so that more effort can be devoted to the real challenge-recovery of at-risk populations.

Finally, the NMFS has not used uncertainty in ESU determinations as an excuse for inaction. For example, the NMFS went forward with final endangered determinations for sockeye salmon from Redfish Lake, Idaho (1991 Federal Register 56:58619), and for cutthroat trout from the Umpqua River in Oregon (1996 Federal Register 61: 41514), in spite of the absence of genetic information for either population and considerable uncertainty in both cases about the relationship between anadromous and resident fish.

A review of the record shows that the NMFS ESU policy can be an effective vehicle for conservation, and I encourage those interested in this issue to examine that record for themselves. Although space limitations do not allow including full citations here, all of the scientific reports describing results of ESA status reviews for Pacific salmonids can be accessed online at [http://www.nwfsc. noaa.gov/pubs/] or can be obtained from the author on request.

\section{Factual Corrections}

There are some errors and misconceptions in the essay by Pennock and Dimmick that need to be addressed. 
First, the statement (p. 616) that "the USFWS and the NMFS recently used the ESU concept for the general definition of distinct population segments under the ESA" is not true. The joint interagency policy does not mention ESUs except to point out that the NMFS salmon policy is based on ESUs. Pennock and Dimmick's use of the term ESU to apply to any method for defining conservation units that uses biological criteria is a source of confusion.

Second, the essay and its appendix contain numerous references to and excerpts from the NMFS interim ESU policy. There is no recognition, however, that the NMFS revised and finalized its ESU policy in 1991 (1991 Federal Register 56:58612), and this final policy has formed the basis for all listing determinations for Pacific salmon since that time.

Third, near the end of their essay Pennock and Dimmick argue that the ESA should be expanded to include protection of distinct populations of plants and invertebrates. This is a reasonable argument that has also been made by others (e.g., National Research Council 1995). Pennock and Dimmick (p. 616) went on to state that "Important groups of plants and invertebrates identified under the ESU concept would not receive protection as distinct population segments under the ESA." This statement is specious. The exclusion of plants and invertebrates from listing as distinct population segments is firmly rooted in the 1978 amendments to the ESA and has nothing to do with the NMFS ESU policy. There is no inherent biological limitation in application of the ESU concept to taxa other than vertebrates, should that become legally possible under the ESA.

\section{Acknowledgments}

I thank M. Ford, S. Grant, J. Hard, L. Jones, M. Nammack, and L. Park for helpful comments on a previous draft, and J. Fay for providing information on U.S. Fish and Wildlife Service listing determinations for distinct population segments.

\section{Literature Cited}

Dizon, A. E., C. Lockyer, W. F. Perrin, D. P. DeMaster, and J. Sisson. 1992. Rethinking the stock concept: a phylogeographic approach. Conservation Biology 6:24-36.

Gleaves, K., M. Kuruc, and P. Montanio. 1992. The meaning of "species" under the Endangered Species Act. The Public Land Law Review 13:25-50.

Mayden, R. L., and R. M. Wood. 1995. Systematics, species concepts, and the ESU in biodiversity and conservation biology. American Fisheries Society Symposium 17:58-113.

Moritz, C. $1994 a$. Defining "evolutionarily significant units" for conservation. Trends in Ecology and Evolution 9:373-375.

Moritz, C. 1994b. Applications of mitochondrial DNA analysis in conservation: a critical review. Molecular Ecology 3:401-411.

National Research Council. 1995. Science and the Endangered Species Act. National Academy Press, Washington, D.C.

Nielsen, J. L., editor. 1995. Evolution and the aquatic ecosystem: defining unique units in population conservation. Symposium 17. American Fisheries Society, Bethesda, Maryland.

Pennock, D. S., and W. W. Dimmick. 1997. Critique of the evolutionarily significant unit as a definition for "distinct population segments" under the U.S. Endangered Species Act. Conservation Biology 11:611-619.

Rohlf, D. J. 1994. There's something fishy going on here: a critique of the National Marine Fisheries Service's definition of species under the Endangered Species Act. Environmental Law 24:617-671.

Rojas, M. 1992. The species problem and conservation: What are we protecting? Conservation Biology 6:170-178.

Vogler, A. P., and R. DeSalle. 1994. Diagnosing units of conservation management. Conservation Biology 8:354-363.

Waples, R. S. 1991. Pacific salmon, Oncorbynchus spp., and the definition of "species" under the Endangered Species Act. Marine Fisheries Review 53:11-22.

Waples, R. S. 1995. Evolutionarily significant units and the conservation of biological diversity under the Endangered Species Act. Pages 8-27 in J. L. Nielsen, editor. Evolution and the aquatic ecosystem: defining unique units in population conservation. Symposium 17. American Fisheries Society, Bethesda, Maryland.

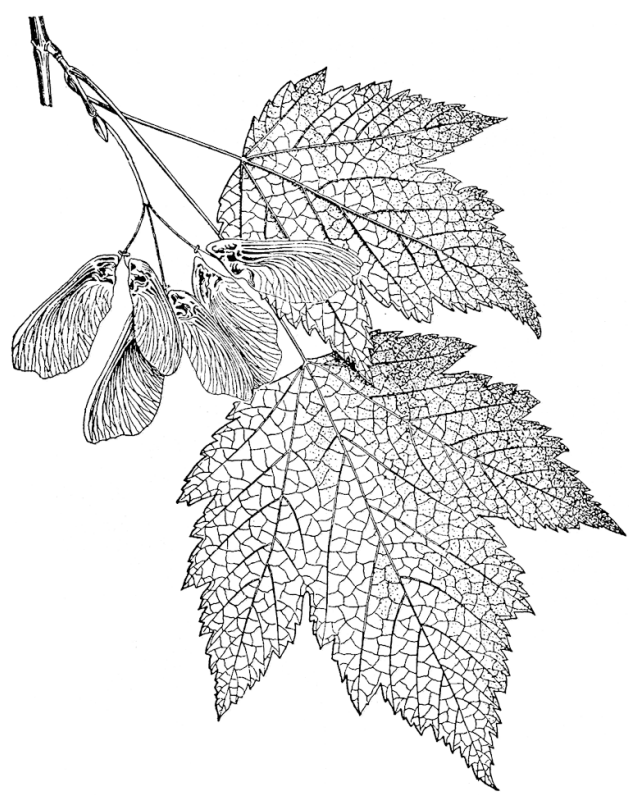

